\title{
UPAYA MENINGKATKAN MOTIVASI DAN HASIL BELAJAR SISWA KELAS VI SDN RANDUAGUNG 02 DENGAN MODEL CONTEXTUAL TEACHING AND LEARNING (CTL) MELALUI METODE VARIASI PADA MATERI LINGKARAN
}

\author{
Sri Sumarni \\ SDN Randuagung 02 \\ Singosari Malang Jawa Timur \\ Email: saya.sumarni@gmail.com
}

\begin{abstract}
Research aimed, wants to know whether learning models Contextual Teaching and Learning (CTL) with a variation of this method can increase motivation and learning outcomes circle mathematics material in Class VI SDN Randuagung 02 Singosari Malang. This research is compiled using classroom action research conducted as many as two rounds or two cycles with the steps: Planning, Implementation, observation, and reflection. Location of the study in SDN Randuagung 02 Singosari Malang. His research is a sixth grade student of SDN Randuagung 02, the number of students 27 children, 13 men and 14 women. From the analysis of the results of observations in the know that the students' motivation has increased which in Cycle I Cycle II $79.9 \%$ and $87.3 \%$ an increase of $7.4 \%$. The results of these observations allow a child to do various activities appropriate observation tool used. While the results of study conducted through the test, after the action is average 67.1 in Cycle I Cycle II 75.2 and at 82.7. The conclusion of this study is the learning model Contextual Teaching and Learning with Variation Method positively affect motivation and learning outcomes Elementary School sixth grade math students Randuagung 02 Singosari Malang.
\end{abstract}

Keywords: contextual teaching and learning, variation method, circle

\begin{abstract}
ABSTRAK
Penelitian ini dilakukan bertujuan, ingin mengetahui apakah model pembelajaran Contextual Teaching and Learning (CTL) dengan Variasi Metode ini dapat meningkatkan motivasi dan hasil belajar matematika materi lingkaran pada siswa kelas VI SDN Randuagung 02 Kecamatan Singosari Kabupaten Malang. Penelitian ini disusun menggunakan Penelitian Tindakan Kelas yang dilakukan sebanyak dua putaran atau dua siklus dengan langkah: Perencanaan, Pelaksanaan, Observasi, dan Refleksi. Lokasi penelitian di SDN Randuagung 02 Kecamatan Singosari Kabupaten Malang. Subjek penelitiannya adalah siswa kelas VI SDN Randuagung 02, jumlah siswa 27 anak, 13 laki-laki dan 14 perempuan. Dari hasil analisis hasil observasi di ketahui bahwa motivasi belajar siswa mengalami peningkatan dimana pada Siklus I 79,9\% dan Siklus II 87,3\% mengalami peningkatan 7,4\%. Hasil observasi ini memungkinkan satu anak melakukan berbagai aktivitas sesuai alat observasi yang digunakan. Sedangkan hasil belajar yang dilakukan melalui tes, setelah tindakan ratarata 67,1 pada Siklus I 75,2 dan pada Siklus II 82,7. Kesimpulan dari penelitian ini adalah model pembelajaran Contextual Teaching and Learning dengan Variasi Metode berdampak positif terhadap motivasi dan hasil belajar matematika siswa kelas VI SDN Randuagung 02 Kecamatan Singosari Kabupaten Malang.
\end{abstract}

Kata kunci: contextual teaching and learning, metode variasi, lingkaran 


\section{PENDAHULUAN}

Harapan yang selalu menjadi tuntutan guru adalah bagaimana bahan pelajaran yang disampaikan dapat dikuasai siswa secara menyeluruh dan tuntas. Ini merupakan masalah yang cukup sulit bagi guru. Kesulitan ini disebabkan oleh metode pembelajaran yang diterapkan kurang memperhatikan kemampuan dan kebutuhan siswa. Siswa dalam pembelajaran tidak hanya sebagai subjek dan objek, namun perlu disadari bahwa mereka individu dengan latar belakang yang berbeda. Perbedaan bisa terjadi dari lingkungan tempat tinggal, aspek intelektualnya, latar belakang ekonomi, maupun secara psikologi.

Hal ini dapat kita lihat dari data yang kami peroleh dari 27 siswa kelas VI SDN Randuagung 02 dalam mengikuti pembelajaran matematika, tiap ada pelajaran matematika selalu ada siswa yang tidak masuk sekolah. Yang aktif bertanya hanya $33,4 \%$ atau 9 siswa, sedangkan $66,6 \%$ atau 18 anak pasif. Anak yang aktif menjawab pertanyaan ada $40,8 \%$ atau 11 siswa, anak yang aktif mengerjakan tugas $70,4 \%$ atau 19 siswa, anak yang aktif dalam proses pembelajaran74,1 atau 20 anak, anak yang aktif berinteraksi dengan teman 59,3\% atau 16 siswa dan melakukan dengan senang hati $66,6 \%$ atau 18 siswa. Anak yang tuntas belajar 16 anak atau 59,3\% sedangkan yang belum tuntas 11 anak atau $40,7 \%$, yang lebih menyedihkan ada 9 anak yang takut pelajaran matematika atau $33,3 \%$.

Selain yang berupa data, materi yang diperoleh siswa di sekolah sebagian besar hanya berifat hafalan dengan tingkat pemahaman yang rendah. Begitu juga pembelajaran yang dikembangkan masih mementingkan transformasi pengetahuan dan masih tervokus pada remidi dan pengayaan. Guru kurang menyentuh aspek pembentukan sikap yang menyebabkan anak menjadi pasif dan tidak mempunyai motivasi belajar. Oleh karena itu, pendekatan Contextual Teaching and Learning dengan variasi metode merupakan suatu cara belajar yang dapat membantu guru dalam situasi pembelajaran dimana guru dapat menghubungkan antara bahan ajar dengan keadaan lingkungan siswa yang sesungguhnya yang dapat mendorong siswa untuk termotivasi dalam belajarnya.

Banyak terbukti pembelajaran yang tertuju pada penguasaan materi ternyata mampu mengingat dan menghafal dalam jangka waktu yang relatif singkat namun tidak mampu mengingat dalam waktu yang cukup lama. Bertitik tolak pada latar belakang permasalahan tersebut diatas, maka dalam proposal ini saya mengambil judul "UPAYA MENINGKATKAN MOTIVASI DAN PRESTASI BELAJAR MATEMATIKA DENGAN MODEL CONTEXTUAL TEACHING AND LEARNING (CTL) MELALUI METODE VARIASI PADA SISWA KELAS VI SDN RANDUAGUNG 02 KECAMATAN SINGOSARI KABUPATEN MALANG.

Berdasarkan rumusan masalah tersebut diatas, maka tujuan penelitian adalah sebagai berikut.

1. Mengetahui peningkatan motivasi belajar siswa kelas VI SDN Randuagung 02 Kecamatan Singosari Kabupaten Malang melalui penerapan metode pembelajaran "Contextual Teaching and Learning dengan Metode Variasi“.

2. Mengetahui peningkatan hasil belajar siswa kelas VI SDN Randuagung 02 Kecamatan Singosari Kabupaten Malang melalui penerapan metode pembelajaran "Contextual Teaching and Learning dengan Metode Variasi“.

1. Manfaat Bagi Siswa

a. Siswa lebih mudah memahami dan menghayati pembelajaran matematika 
b. Menumbuhkan kreatifitas dan motivasi belajar

c. Dapat saling menghargai sesama teman dan mampu berprestasi.

2. Manfaat Bagi Guru

a. Menambah wawasan guru dalam melaksanakan proses pembelajaran

b. Salah satu model pembelajaran alternatif yang dapat membangkitkan motivasi dan prestasi belajar siswa

c. Sebagai bahan dan perbandingan untuk mengadakan penelitian selanjutnya.

3. Manfaat Bagi Peneliti Lain

Bagi peneliti lain yang mengadakan penelitian sejenis dapat digunakan sebagai bahan pertimbangan dan perbandingan sebagai bahan kajian.

\section{METODE PENELITIAN}

Penelitian ini menggunakan rancangan Penelitian Tindakan Kelas. Penelitian ini dilakukan berusa untuk mengkaji dan merefleksi beberapa aspek dalam kegiatan pembelajaran diantaranya, interaksi siswa dengan guru, interaksi siswa dengan siswa dalam rangka untuk menjawab permasalahan yang terjadi pada diri siswa. Pada pelaksanaannya, penelitian ini direncanakan dalam dua siklus yang masing-masing siklus terdiri dari empat langkah sebagai berikut.

1. Perencanaan, yang meliputi merumuskan masalah, menentukan tujuan, metode penelitian, serta membuat rencana tindakan.

2. Tindakan, yang dilakukan sebagi upaya perubahan yang dilakukan.

3. Observasi, dilakukan untuk mengamati hasil atau dampak tindakan terhadap proses pembelajaran.

4. Refleksi, yaitu mengulangi dan mempertimbangkan hasil atau dampak tindakan yang dilakukan.

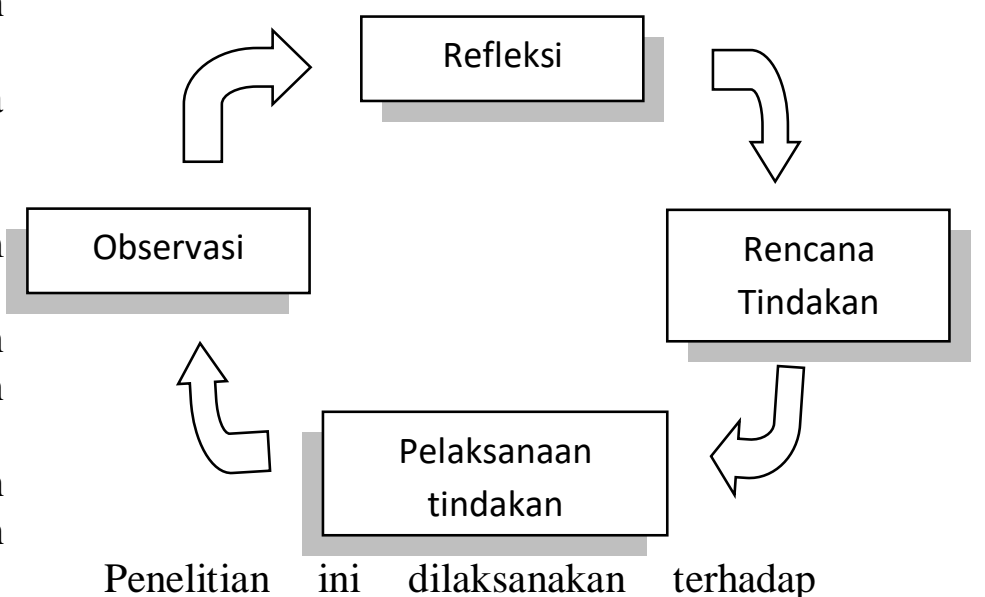
siswa-siswi kelas VI di SDN Randuagung 02 Kecamatan Singosari Kabupaten Malang dengan jumlah siswa 27 anak dengan rincian 13 laki-laki dan 14 perempuan.

a. Lokasi Penelitian

Lokasi penelitian adalah tempat yang digunakan dalam melakukan penelitian untuk memperoleh data yang diharapkan. Penelitian ini bertempat di SDN Randuagung 02 Kecamatan Singosari kabupaten Malang pada tahun pelajaran 2014/2015.

b. Waktu Penelitian

Waktu penelitian adalah waktu berlangsungnya penelitian atau pada saat penelitian ini dilangsungkan. Penelitian ini dilakukan pada bulan Agustus 2014 minggu ketiga dan minggu keempat.

1. Fase Perencanaan ( Siklus I )

Pada tahap perencanaan siklus I peneliti menggunakan pendekatan kontekstual dengan variasi metode yang direncanakan dalam dua siklus. Pada siklus pertama menggunakan metode tanya jawab dan diskusi standar kompetensi menghitung luas segi banyak sederhana, luas lingkaran, dan volume prisma segitiga. Sedangkan kompetensi dasarnya adalah menghitung luas segi banyak yang merupakan gabungan dari dua bangun datar sederhana. Siklus kedua dilaksanakan dengan standar kompetensi yang sama dengan kompetensi dasar menghitung luas lingkaran menggunakan metode diskusi, ceramah, dan tanya jawab 
direncanakan setiap siklus 1 kali pertemuan.

Pada tahap perencanaan tindakan siklus I ini, peneliti melakukan beberapa hal diantaranya.

a. Memilih materi pembelajaran, mencari informasi ke kantor desa, mungkin ada pengukuran tanah milik warga.

b. Menyusun rencana Pelaksanaan Pembelajaran yang berhubungan dengan model kontekstual.

c. Merubah komposisi kelompok, bebas untuk memilih anggota kelompok.

d. Menyiapkan alat peraga yang sesuai dengan materi yang diajarkan berupa potongan - potongan bangun datar yang menunjukkan segi banyak.

e. Menyusun instrumen untuk menekan aktivitas siswa selama proses pembelajaran, terutama yang mengangkat motivasi. Sedangkan penilaian hasil belajar dilaksanakan pada akhir pertemuan di masingmasing siklus.

f. Membuat lembar soal.

g. Membuat kunci jawaban.

h. Membuat lembar catatan lapangan.

2. Fase Tindakan

Pada tahap pelaksanaan tindakan siklus I ini peneliti dibantu oleh teman sejawat melaksanakan skenario pembelajaran yang sudah direncanakan dengan penerapan model pembelajaran "Contextual Teaching and Learning" dengan metode tanya jawab dan ceramah, materi segi banyak sebagai berikut.

a. Guru mengadakan apersepsi dengan cara tanya jawab berkaitan dengan materi bangun datar yang pernah dilihat siswa berada di lingkungan tempat tinggal siswa.

b. Penjelasan guru tentang objek materi yang ada di sekitar sekolah.

c. Guru mebagi siswa menjadi beberapa kelompok untuk setiap kelompok antara 4 s/d 5 anak.

d. Siswa keluar kelas dengan membawa alat ukur (meteran) untuk mengukur objek langsung berkaitan dengan bangun datar antar (segi banyak) yang ada di sekitar sekolah.

e. Siswa kembali ke dalam kelas setelah mengadakan pengamatan dan pengukuran objek yang sesuai dengan materi.

f. Masing-masing kelompok mengadakan pembahasan hasil temuan di lapangan untuk persiapan presentasi di depan kelas.

g. Siswa mempresentasikan hasil pembahasan kelompok di depan kelas.

h. Dalam presentasi, kelompok lain diberi hak untuk mengadakan tanya jawab.

i. Guru bersama siswa menyimpulkan materi pembelajaran.

j. Guru membagikan lembar soal kepada siswa.

k. Menutup pembelajaran dilanjutkan memajang hasil siswa.

3. Observasi

Pada tahap observasi dilakukan selama aktifitas belajar siswa berlangsung baik didalam kelas maupun diluar kelas. Data diambil selama proses pembelajaran berlangsung melalui lembar observasi, sedangkan data hasil belajar diambil melalui hasil tes di akhir pembelajaran.

4. Refleksi

Pada tahap ini peneliti dibantu teman sejawat melalui refleksi terhadap hasil-hasil belajar yang telah dicapai. Baik tingkat kesulitan, dampak dari hasil tindakan terhadap motivasi siswa dan hasil belajar yang telah dicapai untuk bahan pertimbangan sebagai dasar penyususnan RPP Siklus II.

\section{SIKLUS II}

a. Perencanaan

Secara keseluruhan, perencanaan perbaikan pembelajaran pada siklus II adalah sebagai berikut.

1. Memilih materi pembelajaran.

2. Menyiapkan perangkat pembelajaran berupa skenario pembelajaran yang sudah diperbaiki.

3. Menyiapkan media pembelajaran. 
4. Menyiapkan bahan dan alat pembelajaran.

5. Menyiapkan lembar observasi pembelajaran.

6. Menyiapkan lembar evaluasi pembelajaran.

b. Pelaksanaan Tindakan dan Observasi

1. Guru mengadakan apersepsi dengan cara menanyakan pelajaran yang lalu, bagaimana apakah siswa masih mampu mengingat pelajaran yang lalu.

2. Penjelasan guru tentang materi yang akan dibahas, sesuai tugas awal untuk menanyakan perihal kegiatan perangkat desa tentang pengukuran tanah.

3. Guru membagi siswa menjadi beberapa kelompok dan setiap kelompok mencari anggota sendiri yang masing-masing anggota 4 s.d 5 anak.

4. Siswa keluar kelas menuju lokasi pengukuran pada bidang tanah (tidak sesuai rencana perangkat desa tidak ada kegiatan) yang sesuai untuk kegiatan siswa.

5. Kegiatan pengukuran selesai siswa kembali ke kelas untuk mendiskusikan hasil temuan dilokasi kegiatan sebagai persiapan untuk presentasi di depan kelas.

6. Siswa mempresentasikan hasil diskusi di depan kelas.

7. Guru bersama siswa menyimpulkan materi pembelajaran.

8. Guru membagikan lembar soal pada siswa untuk mengetahui sejauh mana penguasaan materi yang telah dirancang sendiri.

9. Guru menutup pembelajaran.

c. Observasi

Pada kegiatan observasi siklus II, peneliti mengevaluasi pelaksanaan tindakan yang telah dilaksanakan. Observasi dilakukan apakah (1) Motivasi anak dalam kegiatan sudah meningkat, (2) Apakah siswa sudah mampu menjelaskan masalah-masalah nyata yang mereka temukan, dan (3) Apakah prestasi siswa sudah meningkat. Motivasi meningkat dapat dilihat pada lembar observasi sedangkan prestasi dapat dilihat dari hasil tes di akhir kegiatan pembelajaran.

d. Refleksi

Refleksi dilakukan dalam kegiatan tersendiri dengan teman sejawat. Peneliti melakukan refleksi berdasarkan temuantemuan yang muncul selam pembelajaran berlangsung. Daftar temuan yang muncul di kegiatan tindakan dapat digunakan sebagai dasar apakah penelitian ini sudah cukup atau dilanjutkan pada siklus berikutnya.

Dalam penelitian ini peneliti menerapkan dua variabel yaitu variabel bebas dan variabel terikat. Variabel bebas diterapkan pembelajaran dalam proses pembelajaran dengan menggunakan model pembelajaran kontekstual dengan metode variasi untuk mengetahui sejauh mana peningkatan motivasi melalui lembar pengamatan pembelajaran matematika. Sedangkan variabel terikatnya adalah verupa hasil belajar yang diketahui dari hasil tes.

a. Teknik Pengumpulan Data

Teknik yang dipergunakan dalam pengumpulan data adalah dengan cara mengadakan pengamatan langsung terhadap objek yang diteliti, yaitu siswasiswi kelas VI SDN Randuagung 02 Kecamatan Singosari Kabupaten Malang. Pengumpulan data dilakukan dengan cara wawancara, melalui lembar observasi dan tes. Wawancara dan observasi dilakukan agar mempunyai gambaran tentang motivasi siswa terhadap pembelajaran Matematika, sedangkan tes mengetahui prestasi siswa dalam menguasai pelajaran matematika.

b. Instrumen Pengumpulan Data

Instrumen adalah alat untuk mengumpulkan data. Instrumen yang digunakan berupa lembar observasi dan lembar soal dalam bentuk tabel-tabel sebagai berikut. 
Jurnal PTK \& Pendidikan

Vol. 3 No. 1. Januari - Juni 2017 (63-76)

Tabel 1 Data Prosentase Ketercapaian Aktivitas

\begin{tabular}{|c|l|c|c|c|}
\hline \multirow{2}{*}{ No } & \multirow{2}{*}{ Kegiatan Siswa Yang Diobservasi } & \multicolumn{2}{|c|}{ Jumlah Siswa } & \multirow{2}{*}{ Prosentase } \\
\cline { 3 - 4 } & & Aktif & Hadir & \multirow{2}{*}{} \\
\hline 1. & Hadir/Masuk Tepat Waktu & & & \\
\hline 2. & Aktif Bertanya & & & \\
\hline 3. & Aktif Menjawab Pertanyaan & & & \\
\hline 4. & Aktif Mengerjakan Tugas & & & \\
\hline 5. & Aktif Dalam Proses Pembelajaran & & & \\
\hline 6. & Berinteraksi Aktif Dengan Teman & & & \\
\hline 7. & Melakukan Dengan Senang Hati & & & \\
\hline
\end{tabular}

Tabel 2 Nilai Ulangan Harian Per Siklus

\begin{tabular}{|c|c|c|c|c|}
\hline \multirow{2}{*}{ No } & \multirow{2}{*}{ Nama Siswa } & \multicolumn{3}{|c|}{ Nilai } \\
\hline & & Sebelum tindakan & Siklus I & Siklus II \\
\hline 1. & Siswa 1 & & & \\
\hline 2. & Siswa 2 & & & \\
\hline 3. & Siswa 3 & & & \\
\hline 4. & dst & & & \\
\hline & JUMLAH & & & \\
\hline & NILAI RATA RATA & & & \\
\hline & PROSENTASE & & & \\
\hline
\end{tabular}

Teknik analisis data menggunakan analisis deskriptif kualitatif untuk mengetahui proses pembelajaran matematika. Sedangkan untuk mengetahui prestasi dan tingkat pemahaman siswa terhadap materi pembelajaran matematika menggunakan analisis deskriptif kualitatif.

Indikator keberhasilan untuk motivasi siswa dalam pembelajaran matematika adalah (1) Hadir/Masuk tepat waktu, (2) Aktif bertanya, (3) Aktif menjawab pertanyaan, (4) Aktif mengerjakan tugas, (5) Aktif dalam proses pembelajaran, (6) Berinteraksi aktif dengan teman, (7) Melakukan dengan senang hati.

a. Rumus untuk menentukan prosentase motivasi belajar siswa pada setiap Indikator adalah.

Dimana:

$$
\%=\frac{\chi}{\sum X} \times 100 \%
$$

$\%=$ Prosentase pengamatan

$\chi=$ Jumlah siswa aktif

$\sum \chi=$ Jumlah siswa hadir

b. Rumus untuk mengetahui peningkatan prestasi belajar siswa adalah

$$
\chi=\frac{\sum \chi}{\sum N}
$$

Dimana : $\sum \chi=$ Jumlah nilai siswa

$\sum \mathrm{N}=$ Jumlah siswa

c. Motivasi belajar siswa dinyatakan meningkat jika rata-rata prosentase menjadi $75 \%$. Apabila belum mencapai $75 \%$ maka dinyatakan belum meningkat.

d. Prestasi belajar siswa dinyatakan meningkat jika rata-rata prosentase menjadi $75 \%$. Apabila belum mencapai $75 \%$ maka dinyatakan belum meningkat.

\section{HASIL DAN PEMBAHASAN}

A. Hasil Penelitian Siklus I

1. Fase Perencanaan

Pada kegiatan perencanaan guru menyusun RPP sesuai Standar Kompetensi. Kompetensi dasar dan materi yang dibahas Standar Kompetensi yang akan dibahas adalah mengjhitung luas segi banyak sederhana, luas lingkaran, dan volume prisma segitiga sedangkan kompetensi dasarnya adalah menghitung luas segi banyak yang merupakan gabungan dari dua bangun datar sederhana.

2. Fase Tindakan dan Observasi

a. Fase Pelaksanaan 
Gambaran umum proses pembelajaran serta situasi selama pembelajaran siklus I berlangsung sebagai berikut:

- Pada awal kegiatan dimulai dengan berdoa lalu mengabsen siswa. Siswa kelas enam ternyata masuk semua.

- Guru mengadakan apersepsi melalui tanya jawab "Benda apa saja yang ada disekeliling kita yang menyerupai bangun datar?". Beberapa siswa mulai berani menjawab, namun masih banyak yang mengambil sikap diam.

- Setelah itu guru menanyakan macammacam bangun datar sebagian siswa bisa menjawab yang lain diam.

- Pembelajaran dilanjutkan dengan menjelaskan tujuan pembelajaran.

- Pada kegiatan inti, guru menyampaikan langkah-langkah pembelajaran.

- Siswa dibagi menjadi 5 kelompok dengan memperhatikan kemampuan siswa sebagai dasar pembagian kelompok. Pembentukan kelompok selesai anak-anak keluar ruang kelas.

- Materi pembelajaran diserahkan pada masing-masing kelompok sesuai dengan pengalaman nyata siswa yang telah diatur sebelumnya. Yaitu mengatur objek langsung yang ada disekitar sekolah (halaman, kebun, atau yang mungkin dapat diambil datanya).

- Dalam tahap ini semua anak mulai melaksanakan tugasnya sesuai dengan objek yang diukur untuk diambil datanya. Ada yang mengeluarkan alat ukur (meteran) kertas sebagai alat penulis data dan ada yang memakai meteran secara berpasangan. Hampir semua kelompok melakukan pekerjaan yang sama, namun sesekali ada yang bertanya kepada ketua kelompok dan kepada sesama teman anggota, namun masih banyak yang pasif bahkan memasukkan jari tangan kedalam saku celananya.

- Selama pengambilan data berlangsung guru memberi motivasi dan penjelasan secukupnya sesuai dengan kebutuhan siswa sambil mengadakan observasi kegiatan yang dibantu oleh teman sejawat.

- Siswa melakukan pengamatan selesai. Selanjutnya masuk ke ruang kelas untuk membahas masalah yang telah ditemukan dalam proses pengukuran objek yang diukur. Yang berupa catatan, gambar yang menunjukkan lebar dan panjang sesungguhnya.

- Guru memantau jalannya diskusi sambil mengatmati melalui lembar observasi.

- Dalam melakukan diskusi kelompok masih banyak siswa yang kurang aktif. Ada yang besandar ditempat duduk, ada yang mengganggu temannya yang sedang membahas hasil penngamatannya. Bila terjadi seperti ini guru baru mengingatkan dan mendekat pada siswa yang bersangkutan untuk segera membantu membahas permasalahan yang mereka dapatkan. Setelah diamati lebih dekat ternyata masing-masing kelompok masih belum bisa bekerja sama sehingga tidak semua masalah dapat dipahami siswa. Selama diskusi kelompok ternyata membutuhkan waktu yang lama karena masih belum bisa bekerja dengan baik.

- Pembahasan di kelompok asingmasing selesai, selanjutnya mempresentasikan hasil diskusi di depan kelas. Dalam pelaksanaan presentasi hasil diskusi kelompok baik yang mempresentasikan maupun peserta masih ada perasaan takut, namun guru segera membimbing agar berani untuk memberi masukan agar hasil presentasi dapat dipahami sema kelompok. Setelah itulah baru banyak siswa yang bertanya dan menyanggah, bahkan jalannya presentasi mulai aktif. Namun satu kelompok tidak melakukan presentasi dengan alasan tidak berani dan takut.

- Presentasi dan pembahsan selesai. Guru membimbing dan mengarahkan 
siswa untuk menyimpulkan materi pembelajaran.

- Untuk mengetahui keberhasilan siswa, guru memberikan tes pada akhir pelajaran.

- Selesai mengerjakan tes, guru dan siswa membahas hasil kerja siswa agar segera diketahui sampai dimana kemampuannya. Letak kesalahan dan akan bangga bila hasil tesnya ternyata benar. Dari hasil evaluasi belum ada yang mendapat nilai sempurna yaitu nilai 100. Paling baik mendapat nilai 90 yaitu Adita Rahma dan M khoirul Huda dan nilai terendah adalah 40.

- Selesai membahas hasil kerja siswa guru mengucapkan selamat kepada siswa yang mendapat nilai terbaik dan memberi reward dengan harapan dapat mempertahankan bahkan lebih meningkatkan nilainya. Bagi siswa yang belum menguasai materi, guru memberi semangat agar lebih giat belajar.

- Mengakhiri pembelajarn guru memberi tugas rumah untuk dibahas pada pertemuan berikutnya. Dan ditutup dengan berdoa dan salam.

b. Fase Observasi

Siklus I dilaksanakan 2 × 35 menit yaitu pada tanggal 18 Agustus 2016. Pada pertemuan ini siswa difokuskan untuk mendalami konsep bangun datar dengan materi luas segi banyak sederhana. Dalam pelaksanaannya, menggabungkan pokokpokok model pembelajaran kontekstual dengan variasi metode. Guru menggunakan metode pembelajaran kontekstual dengan variasi metode berharap dapat mendorong motivasi siswa untuk lebih aktif dalam proses pembelajaran. Observasi dilakukan sepanjang kegiatan pembelajaran berlangsung baik didalam maupun diluar kelas, sehingga tidak menutup kemungkinan 1 (satu) siswa melakukan berbagai aktifitas kegiatan sesuai dengan aspek yang diamati.

tidak semua kelaksanaan observasi, pembelajaran kontekstual terwujud, walupun guru sudah berusaha mengkombinasikan berbagai macam metode. Begitu juga indikator-indikator yang ada di lembar observasi tidak semua berjalan dengan baik, mengingat kemampuan siswa sangat beragam.

c. Aktivitas Siswa Selama Siklus I

Pada Pembelajaran Siklus I yang dilaksanakan selama 2 x 35 menit, keaktifan siswa banyak didominasi oleh ketua kelompok, dan diikuti oleh sebagaian anggota walaupun masih kelihatan canggungnya terutama ketika pelajaran baru dimulai. Hal ini disebabkan ketua kelompok merupakan siswa terpilih diantara siswa yang lain. Berbagai interaksi baru terlihat ketika siswa mencari keluar ruang untuk mengambil objek sesuai dengan materi pembelajaran. Siswa secara kelompok mencari saling bertanya kepada sesama siswa, bertanya kepada guru, diskusi, menjawab pertanyaan teman, namun juga masih dapat kita temui yang masih pasif, memasukkan jari kedalam saku, sambil memandang temanya yang sedang melakukan aktifitas. Berikut ini data aktivitas siswa selama proses pembelajaran.

Berdasarkan tabel 4.1 hasil observasi yang dilakukan oleh teman sejawat pada saat siswa melakukan aktifitas dalam kegiatan pembelajaran masih belum menunjukkan keberhasilan dengan baik. Tercapainya setiap indikator masih belum merata, hal ini dapat dilihat pada tabel 4.2 sebagai berikut. 
Jurnal PTK \& Pendidikan

Vol. 3 No. 1. Januari - Juni 2017 (63-76)

Tabel 4.2 Prosentase Ketercapaian Aktivitas

\begin{tabular}{|c|l|c|c|c|}
\hline NO & \multicolumn{1}{|c|}{ INDIKATOR } & $\begin{array}{c}\text { Jumlah } \\
\text { Siswa } \\
\text { Hadir }\end{array}$ & $\begin{array}{c}\text { Siswa } \\
\text { Aktif }\end{array}$ & Prosentase \\
\hline 1 & Hadir Tepat Waktu & 27 & 27 & $100 \%$ \\
\hline 2 & Aktif Bertanya & 27 & 18 & $66,7 \%$ \\
\hline 3 & Aktif Menjawab Pertanyaan & 27 & 19 & $70,4 \%$ \\
\hline 4 & Aktif Mengerjakan Tugas & 27 & 22 & $81,5 \%$ \\
\hline 5 & Aktif Dalam Proses Pembelajaran & 27 & 21 & $77,8 \%$ \\
\hline 6 & Berinteraksi Aktif Dengan Teman & 27 & 20 & $74,1 \%$ \\
\hline 7 & Melakukan Kegiatan Dengan Senang Hati & 27 & 24 & $88,9 \%$ \\
\hline \multicolumn{3}{|c|}{ Jumlah } & & 559,4 \\
\hline \multicolumn{4}{|c|}{ Rata-rata } \\
\hline
\end{tabular}

Pada akhir pembelajaran Siklus I dilakukan ulangan harian untuk siswa yang semula nilai rata-rata 62,03 mengetahui prestasi belajar siswa. Berdasarkan hasil evaluasi yang telah dilaksanakan terdapat peningkatan nilai menjadi 74,62 mengalami peningkatan $12,50 \%$ untuk lebih jelasnya seperti tabel berikut.

Tabel 4.3 Nilai Ulangan Harian Siklus I

\begin{tabular}{|c|c|c|c|c|}
\hline \multirow{2}{*}{ No } & \multirow{2}{*}{ Nama Siswa } & \multicolumn{3}{|c|}{ Nilai } \\
\hline & & Sebelum Tindakan & Siklus I & Siklus II \\
\hline 1 & Siswa 1 & 75 & 75 & \\
\hline 2 & Siswa 2 & 75 & 80 & \\
\hline 3 & Siswa 3 & 80 & 80 & \\
\hline 4 & Siswa 4 & 75 & 75 & \\
\hline 5 & Siswa 5 & 65 & 75 & \\
\hline 6 & Siswa 6 & 75 & 80 & \\
\hline 7 & Siswa 7 & 50 & 70 & \\
\hline 8 & Siswa 8 & 85 & 90 & \\
\hline 9 & Siswa 9 & 20 & 40 & \\
\hline 10 & Siswa 10 & 80 & 80 & \\
\hline 11 & Siswa 11 & 75 & 80 & \\
\hline 12 & Siswa 12 & 30 & 70 & \\
\hline 13 & Siswa 13 & 60 & 70 & \\
\hline 14 & Siswa 14 & 80 & 80 & \\
\hline 15 & Siswa 15 & 60 & 70 & \\
\hline 16 & Siswa 16 & 80 & 75 & \\
\hline 17 & Siswa 17 & 50 & 80 & \\
\hline 18 & Siswa 18 & 70 & 75 & \\
\hline 19 & Siswa 19 & 65 & 70 & \\
\hline 20 & Siswa 20 & 75 & 80 & \\
\hline 21 & Siswa 21 & 75 & 75 & \\
\hline 22 & Siswa 22 & 60 & 75 & \\
\hline 23 & Siswa 23 & 50 & 75 & \\
\hline 24 & Siswa 24 & 80 & 80 & \\
\hline 25 & Siswa 25 & 75 & 75 & \\
\hline 26 & Siswa 26 & 75 & 75 & \\
\hline 27 & Siswa 27 & 75 & 80 & \\
\hline \multicolumn{2}{|c|}{ Jumlah } & 1810 & 2030 & \\
\hline \multicolumn{2}{|c|}{ Nilai Rata-Rata } & 67,1 & 75,2 & \\
\hline \multicolumn{2}{|c|}{ Prosentase } & $67,1 \%$ & $75,2 \% \%$ & \\
\hline
\end{tabular}

- Kelemahan

3. Fase Refleksi

Dari hasil pengamatan siklus I, maka menghasilkan catatan-catatan kegiatan dalam proses pembelajaran sebagai berikut.
- Guru kurang sabar menunggu hasil kerja siswa sehingga pada waktu presentasi kemampuan anak yang sebenarnya belum nampak, bahkan 
ada salah satu kelompo tidak berani tampil.

- Belum begitu banyak perubahan dalam proses pembelajaran, sebab tidak semua komponen dari tujuh komponen kontekstual belum optimal.

- Waktu yang dibutuhkan dalam proses pembelajaran cukup lama

- Banyak siswa yang belum mampu mengikuti tahapan-tahapan model pembelajaran kontekstual.

- Kelebihan

- Pelaksanaan pembelajaran sudah cukup bagus, motivasi siswa mulai bangkit, prestasi sudah mulai bagus namun masih labil.

- Penggunaan metode sudah cukup bagus.

- Siswa mulai betah dan gembira dalam mengikuti proses pembelajaran.

Hal-hal yang perlu dipertimbangkan adalah :

- Media pembelajaran perlu diperluas agar lebih bervariasi.

- Guru harus segera memberi bimbingan agar siswa lebih berani bertanya, baik siswa dengan siswa, siswa dengan guru, maupun dengan kelompok lain.

- Siswa perlu dilatih untuk presentasi, sebab presentasi adalah bagian dari metode pembelajaran kontekstual yaitu inquiry.

\section{B. Hasil Penelitian Siklus II}

1. Fase Perencanaan

Pada tahap perencanaan guru menyusun RPP, menyiapkan sumber belajar, alat peraga, dan menyusun skenario pembelajaran, alat observasi beserta alat evaluasi. Standar Kompetensi yang akan dibahas, menghitung luas segi banyak sederhana, luas lingkaran, dan volume prisma tegak segi tiga. Sedangkan kompetensinya adalah menghitung luas lingkaran. Pertemuan pada Siklus II ini diharapkan dapat menjawab kelemahankelemahan yang terjadi pada proses pembelajaran siklus I.
2. Fase Pelaksanaan

a. Fase Pelaksanaan

Gambaran umum pelaksanaan tindakan pada Siklus II adalah sebagai berikut.

- Pada awal pembelajaran dimulai dengan berdoa, dilanjutkan dengan mengabsen siswa ternyata siswa kelas VI masuk semua. Selanjutnya guru mengeluarkan bermacam-macam warna bangun datar lingkaran dan diletakkan di atas meja, hampir semua siswa diam, tanpa banyak penjelasan guru menyuruh siswa untuk mengambil bangun datar satu persatu sesuai warna yang disukai. Siswa mulai penasaran, ada banyak siswa yang bertanya ke teman lalu ada pula yang bertanya ke guru. Diantaranya "untuk apa,

- Pak?”. Guru baru menyampaikan tujuan pembelajaran.

- Pada kegiatan inti guru menjelaskan langkah-langkah pembelajaran. Siswa tetap dibagi menjadi 5 kelompok namun yang berbeda dengan Siklus I, pengelompokan sekarang diserahkan pada siswauntuk memilih anggota kelompok sendiri sesuai dengan yang disenangi. Setelah kelompok tertentu, siswa mulai melakukan kegiatan yaitu mengukur keliling, diameter, dan jarijari lingkaran. Terserah lingkaran yang mau diukur yang mana sebab selain lingkaran dari guru siswa juga mempunyai benda berbentuk lingkaran yang dibawa dari rumah.

- Siswa melakukan diskusi, tanya jawab dengan teman sekelompok bahkan ada yang bertanya pada guru, sesuai hal-hal yang ditemukan pada masing-masing kelompok. Dalam kesempatan diskusi ini guru membantu jalannya diskusi dengan harapan semua siswa menggunakan kesempatan bertanya, aktif, dapat menyelesaikan persoalan dan diskusi kelompok dapat selesai tepat waktu.

- Diskusi dalam pemecahan masalah yang berkaitan dengan masalah yang dikaji, tingkat selanjutnya persiapan 
untuk presentasi di depan kelas. Masing-masing kelompok membuat kesepakatan ketika kelompok lain presentasi. Kelompok lain bila belum jelas, bisa bertanya, dan membantu menjawab sehingga semua kelompok paham.

- Presentasi semua kelompok selesai, siswa bersama guru menyimpulkan materi pembelajaran hasil diskusi masing-masing kelompok.

- Untuk mengetahui keberhasilah siswa, guru membagikan lembar soal kepada siswa untuk mengadakan evaluasi.

- Selesai mengerjakan soal, langsung dibahas agar segera megetahui kesalahan sehingga lebih cepat untuk memperbaiki. Hasil evaluasi menunjukkan nilai tertinggi adalah 100 yang diperoleh 4 anak, dan nilai terendah adalah 60 yang hanya diperoleh 1 anak saja. Pelajaran diakhiri dengan berdoa dan salam.

b. Fase Observasi

Pada hari Jumat tanggal 22 Agustus 2016, lama pembelajaran 2 x 35 menit. Pada proses pembelajaran ini Kompetensi Dasar yang dibahas adalah menghitung luas lingkaran dengan indikator mempergunakan rumus untuk mencari luas lingkaran dan menentukan panjang jari-jari jika diketahui luas lingkarannya.
Pada tatap muka Siklus II ini siswa mulai sangat antusias dalam membahas materi. Adanya kerja sama, berani bertanya, memberi jawaban, dan cukup terampil menggunakan alat peraga yang digunakan. Indikator-indikator dalam lembar observasi sudah mulai terisi lebih banyak dibanding dengan Siklus I.

c. Aktivitas Siswa Selama Siklus II

Siklus II yang dilaksanakan selama 2 x 35 menit, selama proses pembelajaran banyak perubahan, dimana pada Siklus II ini keaktifan siswa sudah mulai, merata dibanding dengan siklus I. Keaktifan dapat berubah disebabkan adanya perubahan dalam menentukan kelompok diskusi. Pada Siklus I ketua kelompok ditentukan sedangkan pada Siklus II kelompok dipilih sendiri sesuai dengan yang dikehendaki siswa, hal ini yang menyebabkan kegiatan pembelajaran semakin menaik dan hidup karena masing-masing kelompok brusaha untuk menjadi yang terbaik. Dalam kelompok diskusi tidak ada lagi siswa yang menggoda teman ketika diskusi kelompok. Aktifitas siswa dapat dilihat pada tabel berikut ini.

Aktifitas belajar siswa pada siklus II bila dilihat melalui tabel 4.4 sangat meningkat. Dari ketujuh indikator yang digunakan hampir semua indikator mengalami peningkatan, namun dari 27 siswa dua anak yang sangat pasif dan dapat dilihat pada tabel berikut.

Tabel 4.5 Prosentase Ketercapaian Aktifitas

\begin{tabular}{|c|c|c|c|c|}
\hline NO & INDIKATOR & $\begin{array}{c}\text { Jumlah } \\
\text { Siswa } \\
\text { Hadir }\end{array}$ & $\begin{array}{c}\text { Siswa } \\
\text { Aktif }\end{array}$ & Prosentase \\
\hline 1 & Hadir Tepat Waktu & 27 & 27 & $100 \%$ \\
\hline 2 & Aktif Bertanya & 27 & 19 & $70,4 \%$ \\
\hline 3 & Aktif Menjawab Pertanyaan & 27 & 21 & $77,8 \%$ \\
\hline 4 & Aktif Mengerjakan Tugas & 27 & 24 & $85,9 \%$ \\
\hline 5 & Aktif Dalam Proses Pembelajaran & 27 & 25 & $92,6 \%$ \\
\hline 6 & Berinteraksi Aktif Dengan Teman & 27 & 24 & $88,9 \%$ \\
\hline 7 & Melakukan Kegiatan Dengan Senang Hati & 27 & 25 & $92,6 \%$ \\
\hline \multicolumn{4}{|c|}{ Jumlah } & 611,2 \\
\hline \multicolumn{4}{|c|}{ Rata-rata } & 87,3 \\
\hline
\end{tabular}

sejauh mana keberhasilan siswa dalam

Di akhir pembelajaran guru menguasai materi pembelajaran. Dari mengadakan evaluasi untuk mengetahui 
Jurnal PTK \& Pendidikan

Vol. 3 No. 1. Januari - Juni 2017 (63-76)

hasil evaluasi secara kumulatif mengalami kenaikan. Hal ini dapat dilihat mulai sebelum tindakan adalah 62,03 menjadi 74,62 mengalami peningkatan $12,59 \%$ menjadi 82,59, mengalami peningkatan

Tabel 4.6 Nilai Ulangan Harian Sekolah II

\begin{tabular}{|c|l|c|c|c|}
\hline \multirow{2}{*}{ No Nama Siswa } & \multicolumn{3}{|c|}{ Nilai } \\
\cline { 3 - 5 } & Siswa 1 & Sebelum Tindakan & Siklus I & Siklus II \\
\hline 1 & Siswa 2 & 75 & 75 & 75 \\
\hline 3 & Siswa 3 & 75 & 80 & 80 \\
\hline 4 & Siswa 4 & 80 & 80 & 100 \\
\hline 5 & Siswa 5 & 75 & 75 & 75 \\
\hline 6 & Siswa 6 & 65 & 75 & 90 \\
\hline 7 & Siswa 7 & 75 & 80 & 90 \\
\hline 8 & Siswa 8 & 50 & 70 & 75 \\
\hline 9 & Siswa 9 & 20 & 90 & 100 \\
\hline 10 & Siswa 10 & 75 & 40 & 60 \\
\hline 11 & Siswa 11 & 75 & 80 & 80 \\
\hline 12 & Siswa 12 & 30 & 80 & 80 \\
\hline 13 & Siswa 13 & 60 & 70 & 65 \\
\hline 14 & Siswa 14 & 80 & 70 & 90 \\
\hline 15 & Siswa 15 & 60 & 80 & 85 \\
\hline 16 & Siswa 16 & 80 & 70 & 75 \\
\hline 17 & Siswa 17 & 50 & 75 & 85 \\
\hline 18 & Siswa 18 & 70 & 80 & 90 \\
\hline 19 & Siswa 19 & 65 & 75 & 90 \\
\hline 20 & Siswa 20 & 75 & 70 & 80 \\
\hline 21 & Siswa 21 & 75 & 80 & 100 \\
\hline 22 & Siswa 22 & 60 & 75 & 80 \\
\hline 23 & Siswa 23 & 50 & 75 & 70 \\
\hline 24 & Siswa 24 & 80 & 75 & 80 \\
\hline 25 & Siswa 25 & 75 & 80 & 90 \\
\hline 26 & Siswa 26 & 75 & 75 & 75 \\
\hline 27 & Siswa 27 & 75 & 75 & 75 \\
\hline Jumlah & $67,1 \%$ & 80 & 100 \\
\hline Nilai Rata-Rata & & 2030 & 2235 \\
\hline Prosentase & $75,2 \% \%$ & $82,7 \%$ \\
\hline & & 75 & & \\
\hline & & 75 & 7 \\
\hline
\end{tabular}

\section{Fase Refleksi}

Pada tahap ini akan dikaji apa yang telah terlaksana dengan baik maupun yang kurang baik dalam proses pembelajaran dengan penerapan metode Pembelajaran Contextual Teaching and Learning dengan Variasi Metode. Dan data-data hasil kegiatan pembelajaran yang dalam hal ini dibantu oleh teman sejawat adalah sebagai berikut.

- Selama proses pembelajaran guru dapat melaksanakan proses pembelajaran dengan baik.

- Berdasarkan hasil observasi diketahui bahwa siswa aktif artinya selama proses pembelajaran siswa mempunyai
7,97\% pada Siklus II seperti pada tabel 4.6. 
yang telah direncanakan sudah dianggap cukup dan tidak perlu dilanjutkan pada siklus berikutnya.

\section{Pembahasan}

Berdasarkan hasil observasi Siklus I dan Siklus II siswa hadir $100 \%$, siswa yang aktif bertanya pada Siklus I adalah 18 siswa atau 66,7\%, pada Siklus II 19 siswa atau $70,4 \%$ terjadi kenaikan 3,7\%. Aktif menjawab pertanyaan Siklus I 19 siswa atau 70,4\% pada Siklus II 21 siswa atau $77,8 \%$, mengalami kenaikan 7,4\%. Aktif mengerjakan tugas pada Siklus I adalah 22 siswa atau $81,5 \%$ pada Siklus II 24 siswa atau 88,9\%, mengalami kenaikan $7,4 \%$. Aktif dalam proses pembelajaran Siklus I adalah 21 siswa atau 77,8\% pada Siklus II 25 siswa atau 92,3\%, mengalami kenaikan 14,5\%. Berinteraksi aktif dengan teman Siklus I adalah 20 siswa atau 74,1\% pada Siklus II 24 siswa atau 88,9\%, mengalami kenaikan 14,8\%.Melakukan kegiatan dengan senang hati pada Siklus I 24 siswa atau $88,9 \%$ sedangkan Siklus II 25 siswa atau 92,3\% mengalami kenaikan $3,4 \%$, rata-rata peningkatan motivasi pada Siklus I 79,9\% Siklus II 87,3\%, mengalami peningkatan $7,4 \%$.

Berdasarkan hasil evaluasi yang dilaksanakan pada akhir pembelajaran, mulai sebelum tindakan sampai setelah tidakan Siklus I dan Siklus II adalah sebagai berikut: Sebelum tindakan $67,1 \%$ pada Siklus I 75,2\% mengalami kenaikan $8,1 \%$, sedangkan pada Siklus II 82,7\% mengalami kenaikan 7,5\%. Anak yang tidak tuntas belajar sebelum tindakan 11 anak atau 40,7\%, setelah tindakan Siklus I menjadi 6 anak atau 22,2\%. Setelah tindakan Siklus II menjadi 3 anak atau $11,1 \%$.

Berdasarkan hasil pembahasan, motivasi belajar siswa dalam pembelajaran matematika di kelas VI SDN Randuagung 02 mengalami peningkatan, selain peningkatan motivasi hal yang menggembirakan juga meningkatnya prestasi siswa dalam pembelajaran matematika. Oleh sebab itu, pembelajaran dengan model kontekstual dengan variasi metode dapat meningkatkan motivasi dan prestasi siswa. Hambatan yang ditemukan selama pembelajaran berlangsung adalah sebagai berikut.

1. Pilar-pilar model pembelajaran kontekstual tidak bisa dilaksanakan seluruhnya karena kondisi siswa.

2. Siswa yang tidak bisa mengikuti proses pembelajaran malah tidak aktif dalam proses pembelajaran.

\section{PENUTUP}

Dari hasil kegiatan yang telah dilaksanakan selama dua siklus, berbagai masukan dari teman sejawat, serta hasil pembahasan yang telah dilakukan dapat disimpulkan sebagai berikut.

1. Pembelajaran dengan pendekatan model kontekstual teaching and learning dengan variasi metode memiliki dampak yang positif dalam meningkatkan motivasi belajar siswa dimana pada Siklus I 79,9\% pada Siklus II menjadi 87,3\%, mengalami peningkatan $7,4 \%$.

2. Penerapan pembelajaran dengan model kontekstual teaching and lerning dengan variasi metode dapat meningkatkan prestasi belajar siswa pada setiap siklus, sebelum tindakan $67,1 \%$, tindakan Siklus I 75,2\% meningkat $8,1 \%$. Sedangkan Siklus II $82,7 \%$, meningkat $7,5 \%$.

\section{DAFTAR PUSTAKA}

Anggoro, Toha M. 2004. Metode

Penelitian. Jakarta : Universitas

Terbuka.

Departemen Pendidikan dan Kebudayaan. 2001. Kamus Besar Bahasa Indonesia. Jakarta : Balai Pustaka.

Depdiknas. 2004. Kurikulum Standar Kompetensi Mata Pelajaran Matematika SD MI. Jakarta : Depdiknas.

DePorter, Bobbi. 2007. Quantum Teaching: Mempraktikan Quantum 
Jurnal PTK \& Pendidikan

Vol. 3 No. 1. Januari - Juni 2017 (63-76)

Learning di Ruang-ruang Kelas.

Bandung: KaiFa Mizan Pustaka.

Hasnun M. Sidik, S.Pd.dkk.2007.

Matematika Terampil Berhitung

Jilid 6. Jakarta Erlangga.

Puryanto. 2009. Meningkatkan Prestasi

Belajar Matematika Melalui

Metode Pembelajaran Model

Kontekstual Bernasis Masalah

Pada Siswa Kelas VI SDN

Pondokagung 03 Kasembon.

Universitas Terbuka.

Nurjanah. 2009. Efektifitas Metode

Variasi Dalam Meningkatkan

Prestasi Siswa Kelas IV Semester

Ganjil "MI AL-FATTAH" Kota

Malang Terhadap Materi Sejarah

Kebudayaan Islam. Malang : MI

AL-FATTAH.

Moleong, Lexy J.M.A, Dr. 2002. Metodologi Penelitian Kualitatif.

Bandung : Remaja Rosda Karya.

Wardani, IGAK.dkk. 2007. Penelitian

Tindakan Kelas. Jakarta :

Universitas Terbuka. 